\title{
Stress Concentration in Open Hole Laminate Composites Under Bending: Potential Application in Dental Implant Prosthesis
}

\author{
Harlei Augusto Bueno Alves ${ }^{a}$, Francisco Maciel Monticelic, Carolina Machado Martinelli Lobo ${ }^{a}$, \\ Marcos Yutaka Shiino ${ }^{b *}$ (D)
${ }^{a}$ Universidade Estadual Paulista (Unesp), Instituto de Ciência e Tecnologia, Departamento de Materiais Odontológicos e Prótese, São José dos Campos, SP, Brasil. ${ }^{b}$ Universidade Estadual Paulista (Unesp), Instituto de Ciência e Tecnologia, Departamento de Engenharia Ambiental, São José dos Campos, SP, Brasil. ${ }^{c}$ Universidade Estadual Paulista (Unesp), Faculdade de Engenharia, Departamento de Materiais e Tecnologia, Grupo de Pesquisa de Fadiga e Materiais Aeronáuticos, Guaratinguetá, SP, Brasil.

Received: May 18, 2021; Revised: September 27, 2021; Accepted: September 30, 2021.

\begin{abstract}
Carbon fiber reinforced polymer (CFRP) have been gaining prominence in replacing metallic alloys for infrastructure in prostheses, with the possibility of edentulous patients to acquire fixed prostheses. For this, procedures are required to connect these implants to the implant-supported fixed prosthesis, such as holes and notches that can reduce their mechanical properties. In addition, the infrastructure requires longer cantilevers, causing greater stress on the prosthetic system. Then, the objective is to analyze the stress concentration in the CFRP subjected to bending loads with holes ( 4 and $6 \mathrm{~mm}$ diameter to verify the influence of the diameter-to-width ratio) in four-point-bending test. Two composite laminates were evaluated: one with thermoplastic matrix of poly(phenylene sulphide) PPS; and another with epoxy matrix combined with carbon fibers fabric. The presence of holes in the studied dimensions did not present significant differences in the flexural modulus and maximum bending strength. Therefore, the use of CFRP showed some advantage regarding the reduced effect of stress concentration compared to metallic alloys.
\end{abstract}

Keywords: buckling, fracture, bending moment, residual strength, dental prosthesis.

\section{Introduction}

Lightweight materials with high mechanical properties such as carbon fiber reinforced polymer have been the subject of research in several fields such as transportation, energy, sporting goods, and medical ${ }^{1-4}$. The latter, in the context of prosthesis material, cares of patient welfare that includes the durability under cyclic loading, biocompatibility, and lightweight for mobility ${ }^{5,6}$. For dentistry applications specific for implant-supported prostheses, several locations at the infrastructure are under critical stress, specially that ones with geometries that induce stress concentration such as screwed joints ${ }^{7}$. Carbon fiber reinforced polymer (CFRP) has been clinically tested and its biocompatibility properties are recognized compared with titanium alloys ${ }^{8}$, providing osseointegration in the case of thermoset/carbon fiber composites ${ }^{9}$, also with the advantage of having similar density to human bone ${ }^{10}$. In vitro and in vivo tests have already been performed to attest the feasibility of using PPS-based materials, as they induce cell proliferation, osteogenic differentiation and do not cause irritation or necrosis of cells in rat $\operatorname{skin}^{11,12}$.

Dental prosthesis often needs high strength infrastructure in order to preventing complications such as fractures. In addition, this type of application, it requires that the

*e-mail: marcos.shiino@ict.unesp.br material operates within the limits of elasticity or below, withstanding several types of forces: tensile, compressive, bending, twisting or shearing stresses. It also needs to account for geometric changes that input stress concentration regions, where damages are likely to begin. The bending tests encompass two of the aforementioned forces: tensile and compressive, which allow to determine the flexural strength and modulus using different set-ups according to the material behavior ${ }^{13}$. These are more common forces that appear in human occlusal movements, that induce bending stress in which its magnitude depends on the position of the tooth due to the bending moment: in elderly patients has the capacity to transmit forces to teeth of the order of $408 \mathrm{~N}$ in men; $243 \mathrm{~N}$ in women ${ }^{14}$; and reaching $859 \mathrm{~N}$ in patients of age 20 to 38 years $^{15}$.

The mechanical stresses generated by the masticatory cycles in implant-support of fixed full arch prostheses should not be of great magnitude since this is transferred to the implants and adjacent bone tissues, causing peri-implant bone loss. Therefore, a favorable geometric distribution of implants is extremely important, providing a good occlusal balance, and that the modulus of elasticity is high for the materials used in the prosthetic framework of prosthetic infrastructure, thus ensuring the distribution of masticatory loads more effectively throughout bone tissues ${ }^{16}$. 
Currently, metal alloys are considered the gold standard to guarantee the necessary strength and stiffness of the infrastructure in dental prosthese ${ }^{17}$. Materials such as Au alloys, $\mathrm{CoCr}$, NiCr, Ti and ceramics, such as Zirconia, are used in these infrastructures, due to their high modulus of elasticity (Table 1). However, the development of fiber reinforced polymer with mechanical properties similar to metallic alloys has been proposed as another option in oral rehabilitation ${ }^{25-27}$.

Bränemark's original proposal for the rehabilitation of fully edentulous jaws consisted of the installation of 5 to 6 implants in the mandible region and 6 to 8 in the maxilla ${ }^{28}$, but often for the insertion of this quantity of implants it needs a procedure for bone reconstruction. These end up taking the treatment of two steps surgical procedures, causing an increase in working time, costs and especially the morbidity of such procedures ${ }^{29-31}$. As an alternative to regenerative procedure treatments such as short implants ${ }^{32,33}$, zygomatic fixations ${ }^{34-36}$, and inclined implants ${ }^{37-39}$ have been proposed. Among the techniques for using inclined implants, the "All on Four $\AA$ " technique has been widely used ${ }^{40-42}$, but it can generate long cantilevers, thus impairing the prosthesis biomechanics ${ }^{43-45}$. To overcome those issues, composites have been proposed that use fibers either in the form of fabric or unidirectional laminae. Also, the fibers can be provided as impregnated with resin, thus forming the pre-impregnated fibers (prepregs). In the form of fabrics, they can be in the form of plain weave, satin weave and twill weave ${ }^{46}$.

The use of woven fabrics has increased in the industry with structural applications due to better resistance to interlaminar fracture, when compared to unidirectional fibers, easy handling, and ability to make parts with complex geometries ${ }^{47,48}$. Some variables can affect the performance of the mechanical properties of composites such as fiber length ${ }^{49}$, fiber volume fraction ${ }^{50}$, fiber shape alignment ${ }^{51}$, orientation, and fiber layup ${ }^{52-54}$. Composite material has the advantage of presenting alternatives for manufacturing processes, such as manual molding, filament winding, pultrusion, hot compression molding, autoclave, and resin injection (RTM- resin transfer molding) ${ }^{55}$. They have a high "specific stiffness" (ratio between stiffness and specific mass). For example, composite materials may provide the same stiffness as a steel, but with a reduced specific mass. Thus the "specific resistance" (ratio between resistance and specific mass) of a composite material is quite high. This property can be about 3 to 5 times higher than steel or aluminum alloys ${ }^{56}$.

A challenge of composite laminates is the integration of the parts when they need to be joined to other metallic or composite structures. One way of joining is by riveting and screwing joints to fix the composite structure to other components. This needs holes for joining parts that generates stress concentrators, from which the cracks start ${ }^{57}$.

This research aims to evaluate and compare the stress concentration generated by holes in two composite systems: a thermoplastic composite with poly(phenylene sulphide) (PPS) matrix with woven carbon fiber; and a thermoset epoxy matrix and woven carbon fiber. A notch represented by a central hole with two different diameters was considered for the evaluation. The four-point-bending apparatus was adopted due to the constant maximum moment produced around the holes, thus representing the worst case scenario in a cantilever of the prosthesis infrastructure.

\section{Materials and Process}

Two composite laminates were manufactured for the investigation, a composite reinforced by carbon fibers with a thermoplastic PPS matrix and another composite reinforced by carbon fibers with a thermoset epoxy matrix.

\subsection{Thermoset composite processing}

For the thermoset material, the RTM system (Resin Transfer Molding) was chosen, which consists of a steel mold to which resin is applied under high pressure and temperature is controlled through an RTM equipment, model Radius 2100cc RTM injector. The thermoset matrix used was CYCOM 890® resin supplied by CYTEC, which met the necessary requirements to employ in the RTM process, as it has a low viscosity $(100 \mathrm{mPa} . \mathrm{s})$ at a temperature of $80{ }^{\circ} \mathrm{C}$ that keeps for 2 hours, leading to a high degree of impregnation of the resin into the fibers.

The fiber used was IM7 produced by HEXCEL, which was woven in a $5 \mathrm{HS}$ fabric format with an areal weight of $280 \mathrm{~g} /$ $\mathrm{m}^{2}$, supplied by SIGMATEX (Cheshire, United Kingdom). The 10 layers of $5 \mathrm{HS}$ fabrics were laid up in the $3 \mathrm{~mm}$ mold thickness, in order to reach an adequate fiber volume fraction of $52.43 \%$, calculated according to Equation 1 .

Table 1 - Mechanical properties of various materials applied in Dentistry.

\begin{tabular}{|c|c|c|c|c|c|c|}
\hline \multirow[t]{2}{*}{ Materials } & $\begin{array}{c}\text { Modulus of } \\
\text { elasticity }\end{array}$ & Density & Flexural strength & Specific strength & Specific modulus & References \\
\hline & $(\mathrm{GPa})$ & $\left(\mathrm{g} / \mathrm{cm}^{3}\right)$ & $(\mathrm{MPa})$ & $\left(\mathrm{MPa} / \mathrm{g} / \mathrm{cm}^{3}\right)$ & $\left(\mathrm{GPa} / \mathrm{g} / \mathrm{cm}^{3}\right)$ & \\
\hline Titanium & $110 *$ & $4.50 *$ & $1302 * *$ & 289.33 & 24.44 & $* 18 ; * * 19$ \\
\hline CoCr alloy & $220 *$ & $8.00 *$ & $1896 *$ & 237.00 & 27.50 & $* 18 ; * * 19$ \\
\hline Acrylic Resin & $2.70 *$ & $1.20 *$ & $78 * *$ & 65.00 & 2.25 & $* 18 ; * * 20$ \\
\hline Zirconia & $200 *$ & $5.68 *$ & $628.3 * *$ & 110.6 & 35.21 & $* 18 ; * * 21$ \\
\hline Ti-6Al-4V & $116 *$ & $4.42 * *$ & $1103 *$ & 522.85 & 26.24 & $* 19 ; * * 22$ \\
\hline PEEK (Trinia $\left.{ }^{\circledR}\right)$ & $11.60 *$ & $1.32 * *$ & $254 *$ & 192.42 & 8.79 & $* 23 ; * * 18$ \\
\hline Cortical bone & $13.7 *$ & $2.1 * *$ & & & 6.52 & $* 18 ; * * 24$ \\
\hline Spongy bone & $1.37 *$ & $1.1 * *$ & & & 1.25 & $* 18 ; * * 24$ \\
\hline
\end{tabular}

Legend: The asterisk in the quotes refers to the information on the line in which it is inserted. 
The reinforcement was displaced inside the mold, and the applied injection pressure varied from 1.5 to 9.0 bar until the total impregnation of the resin to the fiber. The heating rate varied from 2 to $4{ }^{\circ} \mathrm{C} / \mathrm{min}$, so that it presented a more effective heat transfer to the composite up to $180{ }^{\circ} \mathrm{C}$ for 2 hours.

\subsection{Thermoplastic material processing}

To produce composite with PPS matrix, the hot compression molding process was carried out by stacking carbon fibers and thermoplastic matrix thin films. HexForce ${ }^{\circledR}$ carbon fibers supplied by HEXCEL Composites of 5HS type with $375 \mathrm{~g} / \mathrm{m}^{2}$ areal weight were used, and the PPS Torelina ${ }^{\circledR}$ thermoplastic matrix was supplied by the Toray in the form of films with a thickness of $0.15 \mathrm{~mm}$ and density of $1.35 \mathrm{~g} / \mathrm{cm}^{3}$.

The fiber volume fraction was also calculated using Equation 1 and the number of layers of polymeric PPS films with Equation 2. Where in Equation $1 V_{f}$ is the volumetric fraction of fibers $(\%) ; g s m$ is the areal weight $\left(\mathrm{g} / \mathrm{m}^{2}\right) ; n p$ is the number of layers of fiber fabrics; $\rho_{f}$ is the fiber density $\left(\mathrm{g} / \mathrm{cm}^{3}\right) ; t$ is the thickness of the mold $(\mathrm{mm})$.

In Equation $2 N_{f}$ is the number of resin sheets; $V_{m}$ is the volume of the mold; $V_{r}$ is the volume of resin. Thus, it was determined that the fiber volume fraction was $52.23 \%$ and for that purpose the number of 10 fabric layers was necessary. And the number of resin sheets was 15 to fill the remaining $47.77 \%$ of the mold volume.

$V_{f}=\frac{g s m \cdot n p}{\rho_{f} \cdot t}$

$N_{f}=\frac{V m}{V r}$

After stacking the layers, the mold was closed and taken to the controlled heating column press, Hidraumak system. The laminate was processed using a controlled press up to 59 bar (22 ton) and controlled temperature up to $300{ }^{\circ} \mathrm{C}$. A cooling rate of $0.30^{\circ} \mathrm{C} / \mathrm{min}$ was followed to extract the laminate from the mold.

\subsection{Specimen preparation and flexural test}

The specimens were sectioned with the final dimensions of $(120 \times 13 \times 4) \mathrm{mm}^{3}$ for carbon/PPS composites and $(120 \times 13 \times 3)$ $\mathrm{mm}^{3}$ for carbon/epoxy composites. The parameters for testing followed ASTM D7264/7264M-15 with a span-to-depth ratio of 33 for carbon/epoxy and 25 for carbon/PPS.

For carbon/PPS, 18 specimens were tested, in which 7 were tested without hole, 6 with a $4 \mathrm{~mm}$ diameter hole, and 5 with $6 \mathrm{~mm}$ diameter holes. Sixteen specimens were produced for carbon epoxy composites: 5 without hole, 6 with a $4 \mathrm{~mm}$ diameter hole and 5 with a $6 \mathrm{~mm}$ diameter hole. The number of specimen is in accordance with international standards that state a minimum of five specimens for exploratory study ${ }^{58}$.

Four-point-bending test apparatus was considered for the analysis of stress concentration due to the maximum constant moment applied at the hole, as shown in Figure 1.

The notch as a circular hole was prepared with a drilling machine with cutting speed of $3000 \mathrm{rpm}$, a feed rate of approximately $0.05 \mathrm{~mm} / \mathrm{rev}$, and followed the width-to- diameter ratio presented in Table 2 . The parameters were based on the results presented in the open literature that reported good drilling conditions to avoid delamination process $^{59}$ that was certified using an optical microscope to ensure good surface finish at the edges. A coated carbide drill with standard twist geometry was employed due to a higher resistance to abrasion against carbon fiber ${ }^{60}$.

The bending tests were performed in a universal testing machine Shimadzu, Autograph AG-X series (Kyoto, Japan). A loading cell of $50 \mathrm{kN}$ was used with a displacement rate of $1.0 \mathrm{~mm} / \mathrm{min}$. The tests were performed in 4 point-bendingtesting with a distance between the supports of $100 \mathrm{~mm}$ and a distance of the loading points equal to $50 \mathrm{~mm}$.

\subsection{Analysis}

The analyzes were conducted by evaluating the stressstrain curves whose values were determined considering Equation 3 and (4), derived from classical beam theory and geometry relation, respectively. In Equation 3, $P$ is the applied load, $L$ is the span length, $w$ is the specimen width, and $h$ the thickness, in Equation $4 \delta$ is the displacement.

$\sigma_{f}=\frac{3}{4} \frac{P L}{w h^{2}}$
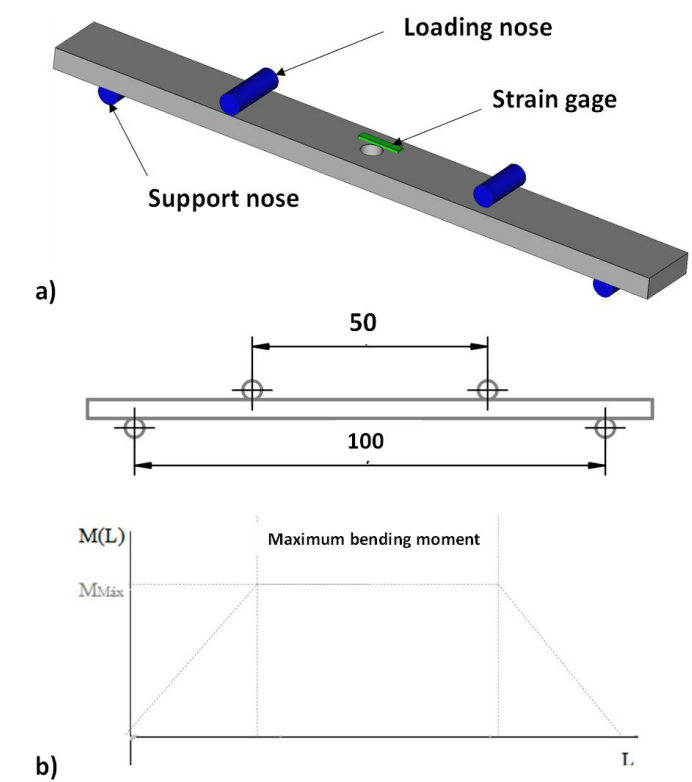

Figure 1. Test apparatus for four-point-bending: a) position of the hole; b) Bending moment diagram.

Table 2. Test conditions for open hole specimens.

\begin{tabular}{cccc}
\hline \multirow{2}{*}{ Laminate } & Hole diameter & & $\begin{array}{c}\text { Radius to width } \\
\text { ratio }\end{array}$ \\
\cline { 2 - 2 } Carbon/PPS & $(\mathrm{mm})$ & $(\mathrm{r} / \mathrm{w})$ \\
\cline { 2 - 3 } & 4.00 & 0.308 \\
\hline \multirow{2}{*}{ Carbon/epoxy } & 6.00 & 0.461 \\
\cline { 2 - 3 } & 4.00 & 0.308 \\
\hline
\end{tabular}




$$
\varepsilon_{f}=\frac{4.36 \delta h}{L^{2}}
$$

With the bending stress and deformation data, the elastic bending module (by the slope method) was calculated, according to Equation 5, which was applied to both specimens without holes and those with holes. In Equation $5 \mathrm{~m}$ is the slope of the secant of the force-deflection curve, $w$ is sample width, and $h$ sample thickness.

$E_{f}^{\text {secant }}=\frac{0,17 L^{3} m}{w h^{3}}$

For the bending test of specimens with holes, the resistant area of the cross- section is decreased by the discontinuity of the hole that is considered in the moment of inertia of the cross-section. Where $I_{f}$ is the moment of inertia of the section with hole in Equation 6 and $r$ is radius of the hole, and replacing in the bending formula leads to Equation 7 , which is the maximum bending strength with a circular hole.

$$
\begin{gathered}
I_{f}=\frac{(w-2 r) h^{3}}{12} \\
\sigma_{f f}=\frac{3 P L}{4(w-2 r) d^{2}}
\end{gathered}
$$

For the calculation of stress concentration $(K)$ in the region of the holes, Equation 8 was used. Where $\varepsilon_{\max }$ is the maximum strain achieved by an extensometer attached tangent to the hole, as shown in Figure $1 \mathrm{~b}$, in the tensile region, and $\varepsilon_{\text {mean }}$ is the mean strain calculated by the displacement of the loading point. For the calculations, it is considered the limit of elasticity, where the relation $\sigma=E \varepsilon$ is valid ( $E$ is the elastic modulus).

$$
K_{t}=\frac{\varepsilon_{\text {max }}}{\varepsilon_{\text {mean }}}
$$

\section{Results}

\subsection{Flexural properties of Carbon/PPS specimens}

The Carbon/PPS composite specimens had a high scatter during the loading process that is related to the variation in the damage processes, which led to a major failure in buckling at the outer fiber in compression side of the bar, where a continuous laminate is more prone to fail ${ }^{61}$. The stress concentration produced by the hole led to less scatter, as depicted in Table 3 . This behavior is attributed to the induced failure at the holes due to maximum stress tangent at the holes.

The stress concentration factor shows more effect when the diameter of the hole increase to a value of $6.00 \mathrm{~mm}$, as depicted in stress-strain curves in Figure 2 at the maximum stress, however none of the two radii to width ratios significantly affects the average maximum strength, considering the high standard deviation values. The holes limited the strain at failure, however for dental structural applications this value can be neglected as it will work below a percentage of the yielding strength.
The average values of maximum flexural properties for the three types of specimens enabled to verify the effect of the stress concentration, observed in Figure 3. It has been already commented the little effect on the maximum strength of the specimens, evidencing that the stress concentrations in the studied range of the radius to width ratios $(r / w)$ were not sufficient for a substantial change in the flexural strength. Therefore, there are a great degree of freedom to employ a variety of screw types and diameters.

Although the flexural strength data are very close in the three studied models, revealing their non-significance, the maximum average force had significantly different values, according to Figure 3. This is meaningful as for a structure with the same dimensions, a hole can reduce the force by approximately $50 \%$ in the case of $6.00 \mathrm{~mm}$ hole. Then, the flexural strength analysis accounts for the reduction of the cross-section area that compensates the reduction in force. The stress is inversely proportional to the cross-section area, as shown in Equation 7, and for the hole diameter of $6.00 \mathrm{~mm}$, this represents a $54 \%$ reduction of the area, showing no effect of the stress concentration $\left(K_{t}\right)$.

The average data of the bending modulus, following Equation 5, showed significant loss of stiffness mainly in the $6.00 \mathrm{~mm}$ diameter hole, as a considerable part of carbon fibers had their load transfer capacity interrupted. Table 4 illustrates the percentage of flexural modulus reduction.

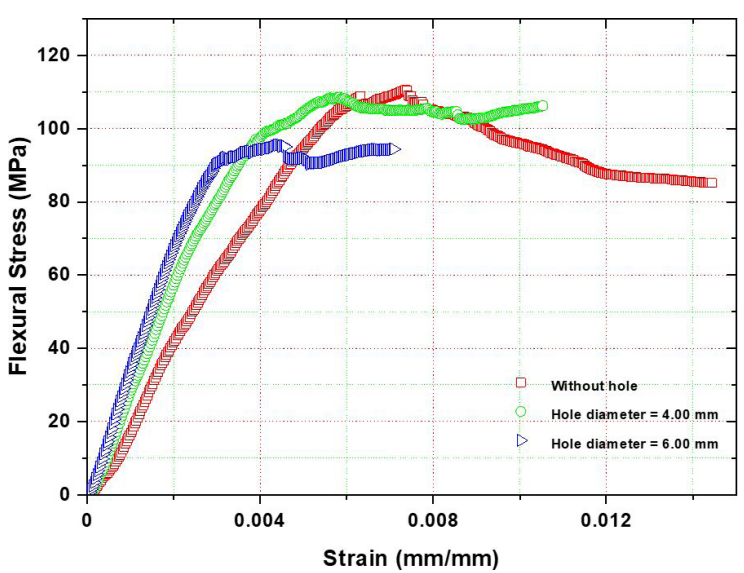

Figure 2. Average values of carbon/PPS specimens with and without holes.

Table 3. Average flexural strength in open hole specimens of Carbon /PPS.

\begin{tabular}{ccc}
\hline Hole diameter & $\begin{array}{c}\text { Average maximum } \\
\text { strength }(\mathrm{MPa})\end{array}$ & $\begin{array}{c}\text { Average maximum } \\
\text { strain }(\mathrm{mm} / \mathrm{mm})\end{array}$ \\
\hline- & $109(31)$ & 0.0072 \\
\hline 4.00 & $117(17)$ & 0.0053 \\
\hline 6.00 & $102(18)$ & 0.0035 \\
\hline
\end{tabular}

Table 4. Flexural modulus of the thermoplastic composites with hole.

\begin{tabular}{cc}
\hline Mean flexural modulus (GPa) & Flexural modulus Reduction (\%) \\
\hline 24.45 & - \\
\hline 22.25 & $9.00 \%$ \\
\hline 14.73 & $39.65 \%$ \\
\hline
\end{tabular}




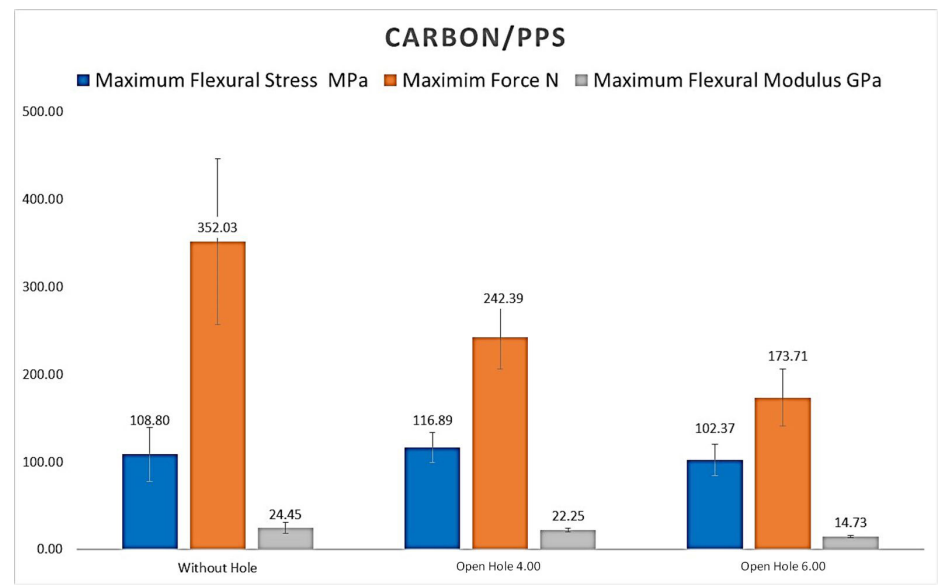

Figure 3. Comparison of the averages of maximum strength, maximum force and maximum flexural modulus for specimens without hole and with hole of 4 and $6 \mathrm{~mm}$.
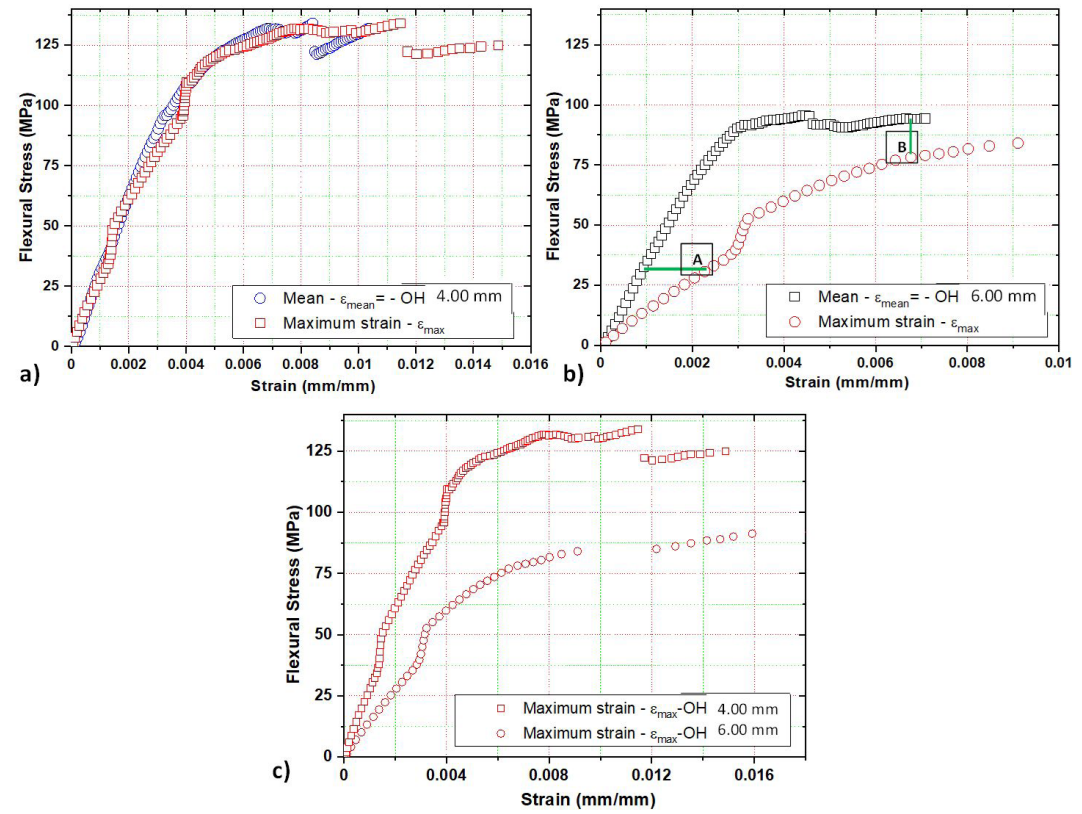

Figure 4. Comparison of mean strain and maximum strain.

Figures $4 a, 4 b$, and $4 c$ show the comparison of the curves for each diameter of hole in order to visualize the magnification of strain near the notch. In Figure 4a, there is no difference in the curves, as a consequence, the laminate is not sensitive to hole diameter of $4.00 \mathrm{~mm}$. A difference is observed in $6.00 \mathrm{~mm}$ hole according to Figure $4 \mathrm{~b}$ that inevitably yields to a $K$ higher than 2.5 taking from the elastic region, detail $A$. However, it was previously stated a negligible effect of $K_{t}$ that is not true, but the behavior beyond the elastic limit led to close values of flexural strength, as shown in Detail $B$. This analysis shows a particular behavior of composites associated with the thermoplastic matrix, that is important to consider the yield strength rather than maximum strength for dental structural application, which suffered a considerable reduction in $6.00 \mathrm{~mm}$ hole diameter.

\subsection{Flexural properties of carbon/epoxy specimens}

The stress versus strain graphic for the thermoset composite can be seen in Figure 5, where it is possible to observe the higher flexural strength in specimens with the presence of stress concentration.

The stress concentrations $\left(K_{t}\right)$ were calculated by means of extensometers positioned tangent to the hole, in which it was found that the magnitude of the maximum stress influenced the result shown in Figure 5. Table 5 shows the calculated $K_{t}$ using strain data.

The data of the flexural properties of the thermoset specimens are shown in Figure 6, in which higher values of 865 (20) and 903 (37) MPa can be observed in the 
specimens with holes of 4.00 and $6.00 \mathrm{~mm}$, respectively, than in specimens without holes with values of 824 (38) MPa. The reasons for these discrepancies could also be attributed to the ratio of reduced force and reduce cross-section area, as occurred in Carbon/PPS composites. However, in Carbon/ Epoxy composites, $K_{t}$ influenced the maximum strength as the failure occurred just at the elastic region due to the brittle nature of the epoxy matrix.

Regarding the modulus, a small difference was observed between specimens with values of 69 (4) GPa, 72 (2) GPa, and 74 (2) GPa for specimens without holes, with 4.00 and $6.00 \mathrm{~mm}$ holes, respectively. The standard deviations shown in these values indicate no influence of the holes in the flexural modulus which is a great advantage in applications that requires high modulus.

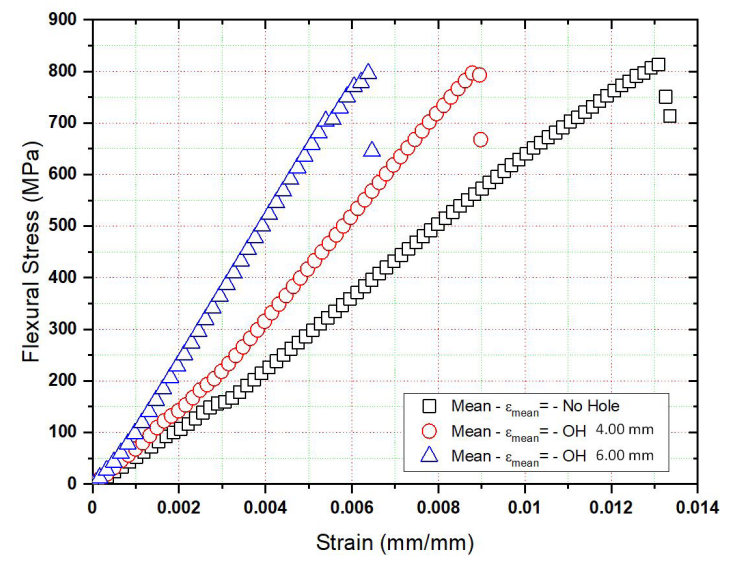

Figure 5. Stress dispersion curves in bending of carbon/epoxy specimens without hole and with hole.

\subsection{Fracture analysis}

The analysis of the fractured surfaces was performed using an optical microscope in order to investigate the failure locus, it is observed that the fracture of the specimens with a notch originated close to the hole in the compression region as seen in Figure 7a, with the fibers buckling in the thermoplastic material. This occurs as the thermoplastic matrix is more susceptible to deform, as a result, the fibers tend to buckle.

In the thermoset materials, the failure occurred in tensile at the outer fiber of the specimen, as can be seen in Figure $7 \mathrm{~b}$. This is a more desirable type of failure by taking full advantage of the fiber strength rather than having the dependency of the matrix strength, as developed in the carbon/PPS composites.

\section{Discussion}

Costa $^{62}$ reports values of 1170 (49) MPa and 61 (1) GPa for flexural strength and flexural modulus, respectively, for carbon/PPS composites, processed by the hot compression molding. In contrast, the results presented in this research were 108 (31) MPa for flexural strength and 25 (6) GPa for flexural modulus for similar material. The main differences between the results were the used raw material, as Costa $^{62}$ used a pre-impregnated carbon fiber with PPS, besides the use of unidirectional fibers aligned in the loading direction provides optimum strength. This research comprised a woven fabric that limits the fibers aligned in loading direction by $50 \%$, in addition, the woven generates crimp regions which induces failure by buckling in the compression side ${ }^{61,63}$. This type of failure was reported in the previous section that comprises the misaligned fiber due to the waviness generated by woven.

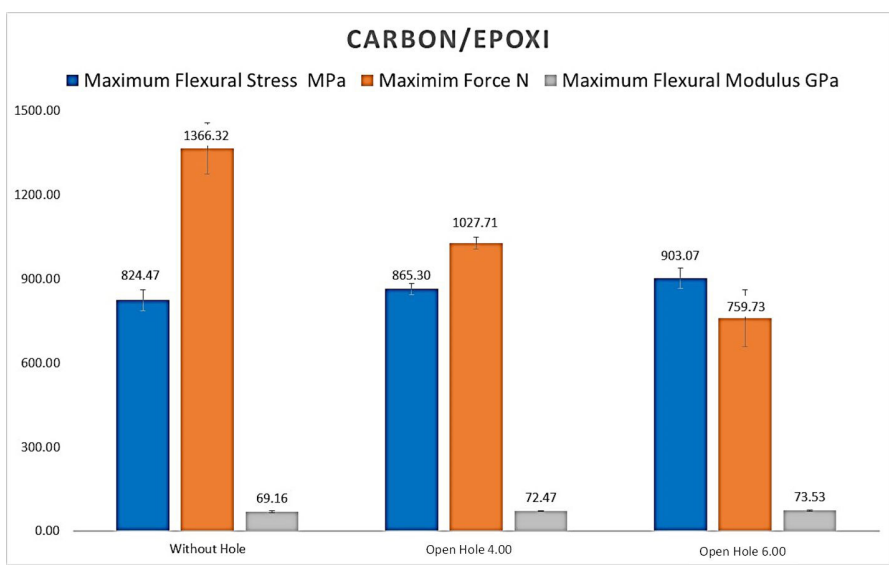

Figure 6. Comparison of the averages of maximum bending strength, maximum force and maximum flexural modulus for specimens without hole and with hole of 4 and $6 \mathrm{~mm}$.

Table 5. Stress concentration $\left(K_{t}^{=}=\varepsilon_{\text {max }} / \varepsilon_{\text {mean }}\right)$.

\begin{tabular}{ccccc}
\hline Specimens & $\varepsilon_{\max }(\mathrm{mm} / \mathrm{mm})$ & $\varepsilon_{\text {mean }}(\mathrm{mm} / \mathrm{mm})$ & $K_{t}$ & Radius to width ratio \\
\hline TR CF4 & 0.000629 & 0.000401 & 1.57 & 0.28 \\
\hline TR CF6 & 0.000504 & 0.000337 & 1.49 & 0.45 \\
\hline
\end{tabular}

TR - Thermorigid CF 4 - Hole diameter equal $4.00 \mathrm{~mm}$ CF6 - Hole diameter equal to $6.00 \mathrm{~mm}$ 
a)
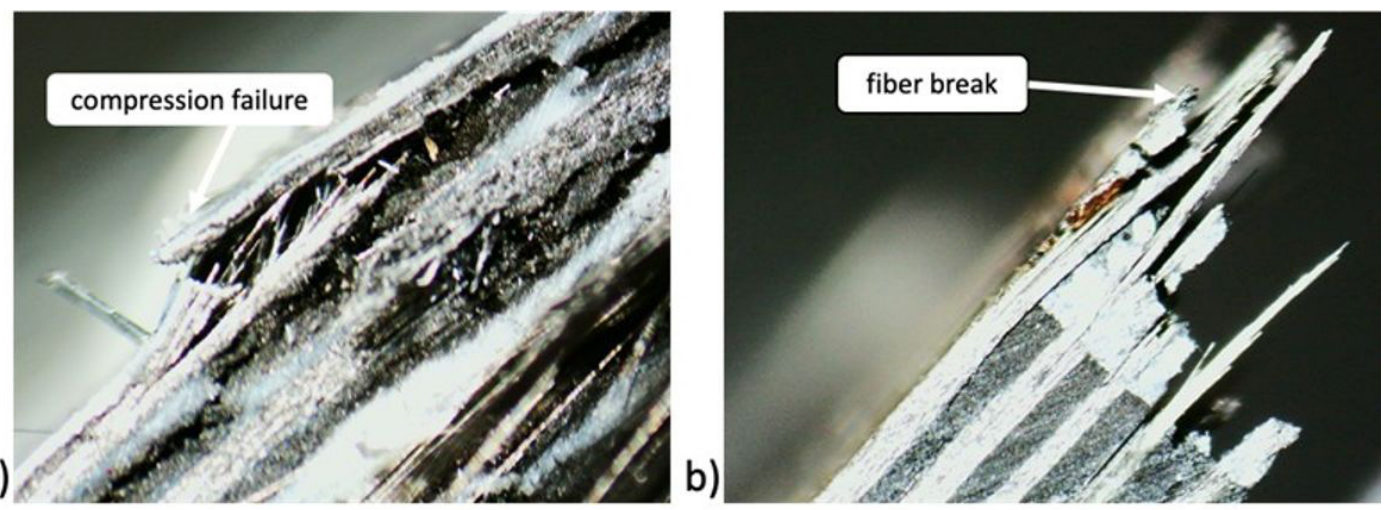

Figure 7. Types of fractures occurring: a) in thermoplastic laminates; b) and in thermoset.

Other factors can be attributed to the decrease in the mechanical properties, mainly during the processing of the thermoplastic material, such as: cooling rate of the laminate; and dry spots ${ }^{64}$. Such alterations generate internal discontinuities in the laminate, such as flaws and voids, which can generate cracks in the matrix, fiber breakage or delamination. Despite the lower performance of the carbon/PPS composite, it overcomes the requirement of minimum strength of $65 \mathrm{MPa}$ for plastic materials applied in dentistry (DIN EN ISO 10477).

The literature provides rich information for carbon fiber/epoxy composites processed by the RTM method ${ }^{65-68}$ and combined to flexural analysis. Brocks et al. ${ }^{66}$ reported values of 884 (42) MPa and 60 (3) GPa for flexural strength and flexural modulus, respectively, which are closed to the values of 824 (38) $\mathrm{MPa}$ and 69 (4) GPa strength and modulus, respectively, obtained in this research. Also, Shiino et al. ${ }^{67}$ found values of 787 (89) MPa for flexural strength and 29 (3) GPa for flexural modulus in three-point-bending test of in quasi-isotropic laminates.

In fatigue, tests with the presence of stress concentrations reported a maximum reduction in strength around $40 \%{ }^{69}$, corroborating with the present study in which there were reductions of $31 \%$ for holes with a diameter of $4.00 \mathrm{~mm}$, and $51 \%$ in holes of $6.00 \mathrm{~mm}$ for the Carbon/PPS composite, while for the Carbon/Epoxy composites the reduction in strength was $29 \%$ and $44 \%$ for $4.00 \mathrm{~mm}$ and $6.00 \mathrm{~mm}$ holes, respectively.

The type of failure that occurred in the specimens during the bending test was consistent with those reported in the literature ${ }^{67,70}$, where for the Carbon/Epoxy specimens, there was failure in tensile side at the outer fibers. After reaching the maximum flexural strength, there was an explosive separation of the specimens without any plastic deformation ${ }^{67}$. In Carbon/ PPS specimens, on the other hand, there was delamination in the region close to compression and the rupture of fibers in the tensile region, however, there was no separation of the parts, as well as in the tests present in the literature $\mathrm{e}^{71,72}$.

The use of infrastructures in composites has recently been explored due to the advantages of having some advantages over metallic alloys, such as high flexural strength, high modulus of elasticity, low specific weight, allowing chemical adhesion of resins on the infrastructure and lower production $\operatorname{cost}^{17,26,27,63,73}$.

The use of a PEEK resin composite associated with glass fibers (Trinia ${ }^{\circledR}$, Shofu, Dental Corporation, San Marcos, CA, USA) as prosthetic infrastructure has been proposed, providing strength of 254.2 (22.3) MPa and an elastic modulus of 7.2 (3.5) GPa obtained in three-point-bending tests ${ }^{19}$. This material has been applied to fixed prostheses on implants by several authors with promising results ${ }^{73-75}$. The present investigation enabled to affirm that carbon/epoxy composites meet that requirement in all stress concentration condition, however, in the carbon/PPS needs further investigation as it has lower flexural properties, but it may overcome other disadvantage such as sudden failure presented in carbon/ epoxy composites.

The carbon/epoxy composite results of specific strength and modulus were superior to $\mathrm{CoCr}$ and Ti6Al4V alloys, thus demonstrating that it can be a candidate for replacing these materials in prosthetic infrastructure, that usually requires hole for attachment.

\section{Conclusions}

The presence of stress concentration (holes) in the studied diameters did not significantly change the maximum strength values and the bending modulus. The central hole increased the maximum stress in the two diameters evaluated in carbon/epoxy laminates, as this property is inversely proportional to the cross-sectional area, therefore did not sufficiently reduced the force to notice a reduction in flexural strength.

The carbon/epoxy thermoset composite had better mechanical performance in four-point bending test than the carbon/PPS thermoplastic composite. However, there was a divergence between the quality of the thermoplastic composite obtained in relation to the thermoplastic composites present in the literature.

Within the limitations of an in vitro study, which is constrained in environmental pressure and temperature, it is possible to state that thermoplastic and thermoset carbon fiber composites can be potential candidates for prosthetic infrastructure due to their high mechanical strength and high modulus, when compared to other materials already used in dentistry such as acrylic resins, composite resin, and fiberglass composites. Carbon/epoxy composites also present comparable mechanical properties in bending to metal alloys, which are still the gold standard in the manufacture of prosthetic infrastructures. 


\section{Acknowledgements}

The authors acknowledge the financial support from FAPESP through grant \# 2017/16160-8.

\section{References}

1. Dorigato A, Fredi G, Pegoretti A. Application of the thermal energy storage concept to novel epoxy-short carbon fiber composites. J Appl Polym Sci. 2019;136(21):47434. http:// dx.doi.org/10.1002/app.47434.

2. Nguyen S, Anthony DB, Qian H, Yue C, Singh A, Bismarck A, et al. Mechanical and physical performance of carbon aerogel reinforced carbon fibre hierarchical composites. Compos Sci Technol. 2019;182:107720. http://dx.doi.org/10.1016/j. compscitech.2019.107720.

3. Song Y, Choi S, Kim S, Roh J, Park J, Park SH, et al. Performance test for laminated-type prosthetic foot with composite plates. Int J Precis Eng Manuf. 2019;20(10):1777-86. http://dx.doi. org/10.1007/s12541-019-00156-3.

4. Sebaey T, Wagih A. Flexural properties of notched carbon-aramid hybrid composite laminates. J Compos Mater. 2019;53(2830):4137-48. http://dx.doi.org/10.1177/0021998319855773.

5. Darwich A, Nazha H, Abbas W. Numerical study of stress shielding evaluation of hip implant stems coated with composite (carbon/PEEK) and polymeric (PEEK) coating materials. Biomed Res. 2019;30(1). http://dx.doi.org/10.35841/ biomedicalresearch.30-18-1048.

6. Gallagher EA, Lamorinière S, McGarry P. Finite element investigation into the use of carbon fibre reinforced PEEK laminated composites for distal radius fracture fixation implants. Med Eng Phys. 2019;67:22-32. http://dx.doi.org/10.1016/j. medengphy.2019.03.006.

7. Greco GD, Jansen WC, Landre J Jr, Seraidarian PI. Stress analysis on the free-end distal extension of an implant-supported mandibular complete denture. Braz Oral Res. 2009;23(2):17581. http://dx.doi.org/10.1590/S1806-83242009000200014.

8. Petersen R. Carbon fiber biocompatibility for implants. Fibers. 2016;4(4):1. http://dx.doi.org/10.3390/fib4010001.

9. Petersen R. Titanium implant osseointegration problems with alternate solutions using epoxy/carbon-fiber-reinforced composite. Metals. 2014;4(4):549-69. http://dx.doi.org/10.3390/ met4040549.

10. Chua CYX, Liu H-C, Di Trani N, Susnjar A, Ho J, Scorrano $\mathrm{G}$, et al. Carbon fiber reinforced polymers for implantable medical devices. Biomaterials. 2021;271:120719. http://dx.doi. org/10.1016/j.biomaterials.2021.120719.

11. Khalili R, Zarrintaj P, Jafari SH, Vahabi H, Saeb MR. Electroactive poly (p-phenylene sulfide)/r-graphene oxide/chitosan as a novel potential candidate for tissue engineering. Int J Biol Macromol. 2020;154:18-24. http://dx.doi.org/10.1016/j.ijbiomac.2020.03.029.

12. Deng Y, Yang Y, Ma Y, Fan K, Yang W, Yin G. Nanohydroxyapatite reinforced polyphenylene sulfide biocomposite with superior cytocompatibility and in vivo osteogenesis as a novel orthopedic implant. RSC Advances. 2017;7(1):559-73. http://dx.doi.org/10.1039/C6RA25526D.

13. Anusavice KJ. Phillips materiais dentários. 12th ed. Rio de Janeiro: Elsevier.

14. Miura H, Watanabe S, Isogai E, Miura K. Comparison of maximum bite force and dentate status between healthy and frail elderly persons. J Oral Rehabil. 2001;28(6):592-5. http:// dx.doi.org/10.1046/j.1365-2842.2001.00716.x.

15. Cosme D, Baldisserotto S, Canabarro S, Shinkai R. Bruxism and voluntary maximal bite force in young dentate adults. Int J Prosthodont. 2005;18:328-32.

16. Skalak R. Biomechanical considerations in osseointegrated prostheses. J Prosthet Dent. 1983;49(6):843-8. http://dx.doi. org/10.1016/0022-3913(83)90361-X.
17. Menini M, Pesce P, Bevilacqua M, Pera F, Tealdo T, Barberis $\mathrm{F}$, et al. Effect of framework in an implant-supported full-arch fixed prosthesis: 3D Finite element analysis. Int J Prosthodont. 2015;28(6):627-30. http://dx.doi.org/10.11607/ijp.4345.

18. Tribst JPM, Dal Piva AMO, Borges ALS, Rodrigues VA, Bottino MA, Kleverlaan CJ. Does the prosthesis weight matter? 3D finite element analysis of a fixed implant-supported prosthesis at different weights and implant numbers. J Adv Prosthodont. 2020;12(2):67. http://dx.doi.org/10.4047/jap.2020.12.2.67.

19. Rocha R, Pinheiro ALB, Villaverde AB. Flexural strength of pure $\mathrm{Ti}, \mathrm{Ni}-\mathrm{Cr}$ and $\mathrm{Co}-\mathrm{Cr}$ alloys submitted to $\mathrm{Nd}$ :YAG laser or TIG welding. Braz Dent J. 2006;17(1):20-3. http://dx.doi. org/10.1590/S0103-64402006000100005.

20. Ali IL, Yunus N, Abu-Hassan MI. Hardness, flexural strength, and flexural modulus comparisons of three differently cured denture base systems. J Prosthodont. 2008;17(7):545-9. http:// dx.doi.org/10.1111/j.1532-849X.2008.00357.x.

21. Paula Miranda RB, Borges R, Marchi J, Lima NB, Cesar PF. Microstructure and flexural strength of the Y:TZP/BG composite. Int J Appl Ceram Technol. 2019;16(5):1979-88. http://dx.doi. org/10.1111/ijac.13306.

22. Yan Y, Nash GL, Nash P. Effect of density and pore morphology on fatigue properties of sintered Ti-6Al-4V. Int J Fatigue. 2013;55:81-91. http://dx.doi.org/10.1016/j.ijfatigue.2013.05.015.

23. Suzaki N, Yamaguchi S, Hirose N, Tanaka R, Takahashi Y, Imazato $\mathrm{S}$, et al. Evaluation of physical properties of fiberreinforced composite resin. Dent Mater. 2020;36(8):987-96. http://dx.doi.org/10.1016/j.dental.2020.04.012.

24. Magalhães K, Fonseca E, Monteiro D. Metodologia para determinação da elevação da temperatura por cimentação ou furação num modelo dentário. In: 5th Congresso Nacional de Biomecânica; 2013; Espinho. Proceedings. Bragança: Sociedade Portuguesa de Biomecânica; 2013 [cited 2021 May 18]. Available from: http://hdl.handle.net/10198/8085

25. Menini M, Pesce P, Pera F, Barberis F, Lagazzo A, Bertola $\mathrm{L}$, et al. Biological and mechanical characterization of carbon fiber frameworks for dental implant applications. Mater Sci Eng C. 2017;70:646-55. http://dx.doi.org/10.1016/j.msec.2016.09.047.

26. Pera F, Pesce P, Solimano F, Tealdo T, Pera P, Menini M. Carbon fibre versus metal framework in full-arch immediate loading rehabilitations of the maxilla: a cohort clinical study. J Oral Rehabil. 2017;44(5):392-7. http://dx.doi.org/10.1111/ joor. 12493 .

27. Castorina G. Carbon-fiber framework for full-arch implantsupported fixed dental prostheses supporting resin-based composite and lithium disilicate ceramic crowns: case report and description of features. Int J Periodontics Restorative Dent. 2019;39(2):175-84. http://dx.doi.org/10.11607/prd.2964.

28. Adell R, Lekholm U, Rockler B, Brånemark P-I. A 15-year study of osseointegrated implants in the treatment of the edentulous jaw. Int J Oral Surg. 1981;10(6):387-416. http:// dx.doi.org/10.1016/S0300-9785(81)80077-4.

29. Raghoebar GM, Louwerse C, Kalk WWI, Vissink A. Morbidity of chin bone harvesting. Clin Oral Implants Res. 2001;12(5):5037. http://dx.doi.org/10.1034/j.1600-0501.2001.120511.x.

30. Nkenke E, Schultze-Mosgau S, Kloss F, Neukam FW, RadespielTröger M. Morbidity of harvesting of chin grafts: a prospective study. Clin Oral Implants Res. 2001;12(5):495-502. http:// dx.doi.org/10.1034/j.1600-0501.2001.120510.x.

31. Pjetursson BE, Tan WC, Zwahlen M, Lang NP. A systematic review of the success of sinus floor elevation and survival of implants inserted in combination with sinus floor elevation. J Clin Periodontol. 2008;35:216-40. http://dx.doi.org/10.1111/j.1600051X.2008.01272.x.

32. ten Bruggenkate CT, Asikainen P, Foitzik C, Krekeler G, Sutter F. Short (6-mm) nonsubmerged dental implants: results of a Multicenter clinical trial of 1 to 7 years. Int J Maxillofac Implant. 1998;13(6):791-8. 
33. Lemos CAA, Ferro-Alves ML, Okamoto R, Mendonça MR, Pellizzer EP. Short dental implants versus standard dental implants placed in the posterior jaws: a systematic review and meta-analysis. J Dent. 2016;47:8-17. http://dx.doi.org/10.1016/j. jdent.2016.01.005.

34. Malevez C, Abarca M, Durdu F, Daelemans P. Clinical outcome of 103 consecutive zygomatic implants: a 6-48 months follow-up study. Clin Oral Implants Res. 2004;15(1):18-22. http://dx.doi. org/10.1046/j.1600-0501.2003.00985.x.

35. Hinze M, Vrielinck L, Thalmair T, Wachtel H, Bolz W. Zygomatic implant placement in conjunction with sinus bone grafting: the "extended sinus elevation technique." a case-cohort study. Int J Oral Maxillofac Implants. 2013;28(6):e376-85. http://dx.doi. org/10.11607/jomi.te18.

36. Aparicio C, Manresa C, Francisco K, Aparicio A, Nunes J, Claros $\mathrm{P}$, et al. Zygomatic implants placed using the zygomatic anatomy-guided approach versus the classical technique: a proposed system to report rhinosinusitis diagnosis. Clin Implant Dent Relat Res. 2014;16(5):627-42. http://dx.doi.org/10.1111/ cid.12047.

37. Naconecy MM, Geremia T, Cervieri A, Teixeira ER, Shinkai RS. Effect of the number of abutments on biomechanics of Branemark prosthesis with straight and tilted distal implants. J Appl Oral Sci. 2010;18(2):178-85. http://dx.doi.org/10.1590/ S1678-77572010000200013.

38. Weinstein R, Agliardi E, Fabbro MD, Romeo D, Francetti L. Immediate rehabilitation of the extremely atrophic mandible with fixed full-prosthesis supported by four implants. Clin Implant Dent Relat Res. 2012;14(3):434-41. http://dx.doi. org/10.1111/j.1708-8208.2009.00265.x.

39. Baggi L, Pastore S, Di Girolamo M, Vairo G. Implant-bone load transfer mechanisms in complete-arch prostheses supported by four implants: A three-dimensional finite element approach. J Prosthet Dent. 2013;109(1):9-21. http://dx.doi.org/10.1016/ S0022-3913(13)60004-9.

40. Maló P, Rangert B, Nobre M. "All-on-Four" immediatefunction concept with Brånemark System ${ }^{\circledR}$ implants for completely edentulous mandibles: a retrospective clinical study. Clin Implant Dent Relat Res. 2003;5:2-9. http://dx.doi. org/10.1111/j.1708-8208.2003.tb00010.x.

41. Balshi TJ, Wolfinger GJ, Slauch RW, Balshi SF. A retrospective analysis of 800 brånemark system implants following the Allon-Four ${ }^{\mathrm{TM}}$ protocol. J Prosthodont. 2014;23(2):83-8. http:// dx.doi.org/10.1111/jopr.12089.

42. Malo P, de Araújo Nobre M, Lopes A, Moss SM, Molina GJ. A longitudinal study of the survival of All-on-4 implants in the mandible with up to 10 years of follow-up. J Am Dent Assoc. 2011;142(3):310-20. http://dx.doi.org/10.14219/jada. archive.2011.0170.

43. White SN, Caputo AA, Anderkvist T. Effect of cantilever length on stress transfer by implant-supported prostheses. Implant Dent. 1995;4(1):63. http://dx.doi.org/10.1097/00008505-19950400000017.

44. Bhering CLB, Mesquita MF, Kemmoku DT, Noritomi PY, Consani RLX, Barão VAR. Comparison between all-on-four and all-on-six treatment concepts and framework material on stress distribution in atrophic maxilla: a prototyping guided 3D-FEA study. Mater Sci Eng C. 2016;69:715-25. http://dx.doi. org/10.1016/j.msec.2016.07.059.

45. de Medeiros RA, Goiato MC, Pesqueira AA, Vechiato AJ Fo, Bonatto LR, Santos DM. Stress distribution in an implant-supported mandibular complete denture using different cantilever lengths and occlusal coating materials. Implant Dent. 2017;26(1):10611. http://dx.doi.org/10.1097/ID.0000000000000534.

46. Levy F No, Pardini LC. Compósitos estruturais: ciência e tecnologia. São Paulo: Edgard Blucher; 2006.

47. Espadas-Escalante JJ, van Dijk NP, Isaksson P. The effect of free-edges and layer shifting on intralaminar and interlaminar stresses in woven composites. Compos Struct. 2018;185:21220. http://dx.doi.org/10.1016/j.compstruct.2017.11.014.

48. Pascal F, Dorival O, Navarro P, Marguet S, Ferrero J-F. Impact damage prediction in thin woven composite laminates - Part I: modeling strategy and validation. Compos Struct. 2018;190:3242. http://dx.doi.org/10.1016/j.compstruct.2018.02.007.

49. Zhang D, He M, Qin S, Yu J. Effect of fiber length and dispersion on properties of long glass fiber reinforced thermoplastic composites based on poly(butylene terephthalate). RSC Advances. 2017;7(25):15439-54. http://dx.doi.org/10.1039/ C7RA00686A.

50. Segerström S, Ruyter IE. Mechanical and physical properties of carbon-graphite fiber-reinforced polymers intended for implant suprastructures. Dent Mater. 2007;23(9):1150-6. http://dx.doi. org/10.1016/j.dental.2006.06.050.

51. Bond I, Hucker M, Weaver P, Bleay S, Haq S. Mechanical behaviour of circular and triangular glass fibres and their composites. Compos Sci Technol. 2002;62(7-8):1051-61. http:// dx.doi.org/10.1016/S0266-3538(02)00035-0.

52. Wang HW, Zhou HW, Gui LL, Ji HW, Zhang XC. Analysis of effect of fiber orientation on Young's modulus for unidirectional fiber reinforced composites. Compos, Part B Eng. 2014;56:7339. http://dx.doi.org/10.1016/j.compositesb.2013.09.020.

53. Almeida JHS Jr, Angrizani CC, Botelho EC, Amico SC. Effect of fiber orientation on the shear behavior of glass fiber/ epoxy composites. Mater Des. 2015;65:789-95. http://dx.doi. org/10.1016/j.matdes.2014.10.003.

54. Ladani RB, Wu S, Kinloch AJ, Ghorbani K, Mouritz AP, Wang $\mathrm{CH}$. Enhancing fatigue resistance and damage characterisation in adhesively-bonded composite joints by carbon nanofibres. Compos Sci Technol. 2017;149:116-26. http://dx.doi.org/10.1016/j. compscitech.2017.06.018.

55. Pardini LC, Gonçalves A. Processamento de compósitos termoestruturais de carbono reforçado com fibras de carbono. J Aerosp Technol Manag. 2009;1(2):231-41. http://dx.doi. org/10.5028/jatm.2009.0102231241.

56. Mazumdar S. Composites manufacturing. Boca Raton: CRC Press; 2001.

57. Bao H, Liu G. Progressive failure analysis on scaled open-hole tensile composite laminates. Compos Struct. 2016;150:173-80. http://dx.doi.org/10.1016/j.compstruct.2016.05.017.

58. American Society for Testing and Materials. ASTM D790: standard test methods for flexural properties of unreinforced and reinforced plastics and electrical insulating materials. West Conshohocken: ASTM International; 2002. p. 1-12.

59. Geng D, Liu Y, Shao Z, Lu Z, Cai J, Li X, et al. Delamination formation, evaluation and suppression during drilling of composite laminates: a review. Compos Struct. 2019;216:168-86. http:// dx.doi.org/10.1016/j.compstruct.2019.02.099.

60. David-Müzel S, Bonhin EP, Ribeiro MV, Botelho EC, Alves MCS. Furfuryl resin/CNT/carbon fiber drilling, using carbide drill coated with Balinit-Helica. Mater Manuf Process. 2020;35(10):1096-103. http://dx.doi.org/10.1080/10426914. 2020.1765252 .

61. Shiino MY, Cioffi MOH, Voorwald HCJ, Ortiz EC. Tricot stitched carbon fiber reinforced polymer composite laminates manufactured by resin transfer molding process: c-scan and flexural analysis. J Compos Mater. 2013;47(14):1695-703. http://dx.doi.org/10.1177/0021998312450928.

62. Costa G. Avaliação da influência dos ciclos térmicos nas propriedades dos compósitos termoplásticos de pps e pei com fibras de carbono e vidro conformados por prensagem a quente [dissertação]. São José dos Campos: Instituto Tecnológico de Aeronáutica; 2006.

63. Pesce P, Lagazzo A, Barberis F, Repetto L, Pera F, Baldi $\mathrm{D}$, et al. Mechanical characterisation of multi vs. uni-directional carbon fiber frameworks for dental implant applications. Mater 
Sci Eng C. 2019;102:186-91. http://dx.doi.org/10.1016/j. msec.2019.04.036.

64. Ashir M, Nocke A, Bulavinov A, Pinchuk R, Cherif C. Influence of defined amount of voids on the mechanical properties of carbon fiber-reinforced plastics. Polym Compos. 2019;40(S2):E1049-56. http://dx.doi.org/10.1002/pc.24820.

65. Barandun GA, Ermanni P. Process development for complex resin transfer molding (Rtm) components: optimization of resin. In: 10th International Conference on Flow Processes in Composite Materials (FPCM10); 2010; Ascona, Switzerland. Abstracts. Plymouth: University of Plymouth; 2010.

66. Brocks T, Shiino MY, Cioffi MOH, Voorwald HJC, Caporalli A Fo. Experimental RTM manufacturing analysis of carbon/epoxy composites for aerospace application. Mater Res. 2013;16(5):117582. http://dx.doi.org/10.1590/S1516-14392013005000107.

67. Shiino MY, Cioffi MOH, Voorwald HJC. Evaluation of stitched fabric composite processed by RTM in quasi-static test. Procedia Eng. 2011;10:2603-8. http://dx.doi.org/10.1016/j. proeng.2011.04.434.

68. Shiino MY, Alderliesten RC, Pitanga MY, Cioffi MOH. Fatigue crack growth rate in mode $\mathrm{i}$ of a carbon fiber $5 \mathrm{HS}$ weave composite laminate processed via RTM. Adv Mat Res. 2014;891-892:172-7. http://dx.doi.org/10.4028/www.scientific. net/AMR.891-892.172.

69. Yudhanto A, Iwahori Y, Watanabe N, Hoshi H. Open hole fatigue characteristics and damage growth of stitched plain weave carbon/epoxy laminates. Int J Fatigue. 2012;43:12-22. http://dx.doi.org/10.1016/j.ijfatigue.2012.02.002.

70. Brocks T, Cioffi MOH, Voorwald HJC. Effect of fiber surface on flexural strength in carbon fabric reinforced epoxy composites. Appl Surf Sci. 2013;274:210-6. http://dx.doi.org/10.1016/j. apsusc.2013.03.018.

71. Marques LS. Estudo do processamento de compósitos termoplásticos PPS/carbono obtidos por consolidação em autoclave [dissertação]. São José dos Campos: Instituto Tecnológico de Aeronáutica; 2010.

72. Batista N. Estudo do efeito da cristalinidade nas propriedades mecânicas de compósitos termoplásticos com aplicações aeronáuticas [tese]. Guaratinguetá: Universidade Estadual Paulista; 2015.

73. Seemann R, Marincola M, Seay D, Perisanidis C, Barger N, Ewers R. Preliminary results of fixed, fiber-reinforced resin bridges on four 4- $\times 5$-mm ultrashort implants in compromised bony sites: a pilot study. J Oral Maxillofac Surg. 2015;73(4):63040. http://dx.doi.org/10.1016/j.joms.2014.10.031.

74. Rolf E, Paolo P, Vincent JM, Mauro M, Richard W, Rudolf S. Metal-free restorations. Implants [serial on the Internet]. 2017 [cited 2021 May 18];1:22-7. Available from: https://www.bicon. com/news/pdf/Implants117Ewers.pdf

75. Yilmaz B, Batak B, Seghi RR. Failure analysis of high performance polymers and new generation cubic zirconia used for implantsupported fixed, cantilevered prostheses. Clin Implant Dent Relat Res. 2019;21(6):1132-9. http://dx.doi.org/10.1111/cid.12844. 